\title{
Scale Economies, Scope Economies, and Technical Change in Federal Reserve Payment Processing
}

\author{
Robert M. Adams, ${ }^{* * *}$ Paul W. Bauer, ${ }^{\dagger}$ and Robin C. Sickles ${ }^{\ddagger}$ \\ * Board of Governors of the Federal Reserve System, Washington, DC 20551, USA \\ † Federal Reserve Bank of Cleveland, Cleveland, Ohio 44101 USA \\ $\ddagger$ Department of Economics, Rice University, Houston, Texas 77005 USA
}

December 17, 2002

\begin{abstract}
In the past decade, the US economy has witnessed a tremendous surge in the usage of electronic payment processing services and an increased importance of the firms that provide these services. In this paper, we estimate scale economies, scope economies, and technical change in the Federal Reserve's provision of payments processing from 1990-2000. We find considerable scale economies and evidence of some scope economies for the provision of automated clearinghouse, fedwire, and book-entry services no matter whether we specify a separable quadratic or a translog cost function. In addition, we find that disembodied technical change also contributed to the overall reduction in costs throughout the 1990s.

Key words: Productivity, Scope Economies, Scale Economies, Technical Change, Financial Institutions.
\end{abstract}

\footnotetext{
${ }^{*}$ This paper reflects the views of the authors and not necessarily those of the Federal Reserve Bank of Cleveland or of the Board of Governors of the Federal Reserve System. We would like to thank Diana Hancock, Ron Borzekowski, and Elizabeth Kiser for their comments.
} 


\section{Introduction}

This paper considers the roles of scale economies, scope economies, and technical change in electronic payments processing. Federal Reserve data for automated clearinghouse (ACH), Fedwire, and Book-Entry products are used to assess how costs vary when multiple electronic payment services are provided. According to current Federal Reserve policy, costs are recovered for these products individually without consideration of the effects from other products (as if separate firms provided each product). ${ }^{1}$ From a policy perspective, the existence of significant scope economies would indicate that the Federal Reserve may need to continue providing a specific service in order to produce all services at the lowest possible cost. The existence of scope economies also implies private networks that offer similar services may be able to lower their costs by providing other financial services. Significant scale economies would indicate that the Federal Reserve can reduce its costs by increasing the size of operation for any one product.

Discerning the cost structure of the payments processing industry is important for several reasons. First, we are able to investigate how the introduction of new computer systems and software improvements have reduced costs. For example, the Fed has consolidated its processing to three main computer centers and adopted a common software platform for the provision of these services. Our study of scale and scope economies and technical change would indicate much about the effect of these changes. Second, little entry has occurred in the provision of automated clearinghouse services. The Federal Reserve accounts for the lion's share of the automated clearinghouse. Some major networks such as Electronic Payments Network, MasterCard, Visa, and a few ATM regional networks have attempted entry with limited success. The Federal Reserve enjoys an even larger market share for marketable US Treasury Securities. In contrast, the Clearing House Interbank Payments System (CHIPS) has gained substantial inroads into the Fedwire market by providing a

\footnotetext{
${ }^{1}$ See Federal Reserve Regulatory Services, Federal Reserve Board Publications Office, Transmittal 165, page 7-37 (11/94)
} 
similar product. ${ }^{2}$ These firms all offer similar networking services. Scale and scope economies in the provision of payment services may shed light on the necessary conditions for substantial entry. Finally, since public data on private payments processing are not easily obtained and since the Federal Reserve has access to the same technologies used in the private sector, our analysis of the Federal Reserve provision of payments processing could give valuable insight into the cost structure of the private provision of payment services.

Since the Monetary Control Act of 1980, the Federal Reserve has been required to offer payments processing services to all banks. ${ }^{3}$ The Federal Reserve must provide these services at a price that covers the full economic costs, including a normal economic profit. With changing financial markets and increasing private provision of these services, an analysis of the cost structure, specifically scale economies, scope economies, and technical change, aids the Federal Reserve in making policy decisions regarding pricing and provision. For example, in the past decade, the Federal Reserve has lowered its price for several services. Often, cost savings from utilizing scale or scope economies are cited as a reason for lower prices. Furthermore, the Federal Reserve has made several improvements to its payments processing system. For example, since 1993, the Federal Reserve has moved to centralize its payments processing to three centers. This process was completed in 1997. Throughout the 1990s, system software was standardized and improved across the Reserve Banks.

In this paper, we will focus on three Federal Reserve electronic payment services: ACH, BookEntry securities, and Fedwire. These services have been considered in several studies. Humphrey (1984) reported the existence of large scale economies for ACH and Book Entry securities, but reported that Fedwire has constant returns to scale. Bauer and Ferrier (1996) found large scale economies for ACH, but Fedwire scale economies appeared to be almost exhausted. Finally, Han-

\footnotetext{
${ }^{2}$ The CHIPS Fedwire product is not a perfect substitute because it does not provide finality and daylight overdrafts for transactions (see BIS Payments System in the Group of Ten Counties, 2000). CHIPS is also a net settlement system.

${ }^{3}$ We will use the term bank to refer to all depository financial institutions. Prior to 1980, Federal Reserve payment services were available only to members of the Federal Reserve System.
} 
cock, Humphrey, and Wilcox (1999) found strong evidence for scale economies for Fedwire using panel data. No paper has considered scope economies.

There are strong reasons to believe that the costs of providing these services are interdependent and that there could be both scale and scope economies. These payment services are provided through an electronic "pipeline". A large share of the cost of providing these service is the cost of installing and maintaining the communications system. As discussed previously, studies using single product cost functions have tended to confirm the existence of scale economies. Because these services share this communications network and some support staff and backup facilities, it is also widely thought that there are scope economies among these services.

The paper is organized in the following manner. Section 2 details the three payment services analyzed in this paper. Section 3 describes the cost function and the notion of scale and scope economies. Section 4 describes the data and section 5 the results. Section 6 concludes.

\section{Electronic Services of the Federal Reserve}

Because the characteristics of Federal Reserve electronic services are not widely known by nonpayment specialists, this section briefly describes the three electronic payment services that we study. $^{4}$

\section{Automated Clearinghouse Services}

The ACH system is a value-dated electronic funds transfer system that can be used to make either credit or debit transfers. Designed as an electronic replacement for paper checks, ACH transactions can be used to transfer funds between individual bank accounts and requested transactions may be denied if the transferring account lacks sufficient funds. The full social cost of processing an ACH item is only about one-third to one-half as much as for a paper check (see Humphrey and

\footnotetext{
${ }^{4}$ For a more complete survey of payment services, see Berger, Hancock, and Marquardt (1996) and Hancock and Humphrey (1997).
} 
Berger, 1990 and Wells, 1994). ACH transactions also now offer businesses potential cost savings by combining electronic remittance data and electronic funds transfers. ${ }^{5}$ Reserve Banks handled about 88 percent of the roughly 4.8 billion commercial and government ACH transactions processed in $2000 .^{6}$

\section{$\underline{\text { Fedwire Service }}$}

The Fedwire funds transfer service is a real-time, gross settlement system between banks in which the sender of funds initiates the transfer. Banks that maintain a reserve or clearing account with a Federal Reserve Bank may use Fedwire to send payments to or receive payments from other account holders for their clients. In contrast with ACH payments, which take two days to process, Fedwire is an immediate payment mechanism and is therefore used for time-critical payments. Fedwire transfers are used primarily for payments related to interbank overnight loans, interbank settlement transactions, payments between corporations, and settlement of securities transactions. In 2000, Reserve Banks processed over 223 million transactions valued at about $\$ 380$ trillion.

\section{Book-Entry}

Book-Entry is closely related to Fedwire and includes all processes, operations, and related expenses associated with establishing, maintaining, and servicing book-entry safekeeping accounts. In effect, a Book-Entry transaction is a Fedwire transaction linked to the transfer of a security. Settlement for most U.S. government securities occurs over this system. ${ }^{7}$ Approximately 29 million transactions were initiated in 2000 over this service, involving securities valued at $\$ 192$ trillion. Although Reserve Banks maintain about 25,000 safekeeping accounts, only a small percentage of these account for most of the volume. In fact, about half of this volume flows between two large money center banks.

\footnotetext{
${ }^{5}$ See Knudson, Walton, and Young (1994) for a discussion of the potential benefits of financial electronic data interchange for business payments.

${ }^{6}$ See bank of International Settlements (2000).

${ }^{7}$ Transactions occur in a real-time delivery-versus-payment (DVP) gross settlement system. DVP systems minimize credit risk because the security is "delivered" immediately and simultaneously with the payment for that security.
} 


\section{Cost Function Estimation}

The analysis of this paper is based on the cost function. It is well known that the cost function is a function of input prices and outputs, which is nondecreasing in outputs and linearly homogeneous in input prices. It can be used to identify scale and scope economies and technical change.

Let $C_{i t}$ be the level of observed total cost by the $\mathrm{i}$-th $(\mathrm{i}=1, \ldots, \mathrm{N})$ processor in period $\mathrm{t}(\mathrm{t}=1, \ldots, \mathrm{T})$, $Y_{i t}$ be the vector of output quantities $(\mathrm{ACH}$, Fedwire, and Book-Entry) produced by the i-th processor in period t, $P_{i t}$ be the vector of input prices (labor, materials, communication equipment and transit, and buildings) facing each processor $\mathrm{i}$ in period t. A stochastic cost function can be written as

$$
C_{i t}=C\left(Y_{i t}, P_{i t} ; \theta\right)+\mu_{i t}
$$

where $\theta$ represents estimated parameters and $\mu_{i t}$ represents random error. We report results from two functional forms in our analysis, translog and separable quadratic. Both belong to the class of separable, quadratic functional forms. ${ }^{8}$

We use the translog functional form as a baseline for our analysis, since the translog has been used previously in productivity studies of payment processing and extensively applied in the banking literature. Dropping observation subscripts, it is defined as:

\footnotetext{
${ }^{8}$ Other functional forms such as composite and generalized composite were used with varying degrees of success. However, these other functional forms were rejected, because either they did not converge or they produced implausible results - negative marginal costs or unbelievable scale (or scope) economies. For the same reasons, we only consider a homothetic cost function with no input price - output interactions. See Berger and Mester (1997) for a comparison of the translog and other functional forms (e.g. Fourier-flexible).
} 


$$
\begin{gathered}
\ln C=\alpha_{0}+\sum_{k=1}^{K} \beta_{k} \ln p_{k}+\frac{1}{2} \sum_{k=1}^{K} \sum_{l=1}^{K} \beta_{k l} \ln p_{k} \ln p_{l}+\sum_{m=1}^{M} \alpha_{m} \ln y_{m} \\
+\frac{1}{2} \sum_{m=1}^{M} \sum_{l=1}^{M} \alpha_{m l} \ln y_{m} \ln y_{l}+\lambda_{1} t i m e+\lambda_{2} t i m e^{2} \\
+\sum_{j=1}^{3} \phi_{j} Q T R_{j}+\mu_{i t} \\
k=1, \cdots, 4 ; m=1, \cdots, 3 ;
\end{gathered}
$$

where QTR represents quarterly dummies, time and time $e^{2}$ time trends, and $\mu_{i t}$ is random error. We use time and time $e^{2}$ variables as a proxy for technological change. ${ }^{9}$

It is well known that the translog functional form is not well defined around regions of zero production levels. This trait of the translog makes it undesirable to estimate scope economies (Röller, 1990). We also estimate a separable quadratic functional form, which is flexible and overcomes this shortcoming. It is quadratic in outputs and easily allows for zero production levels in outputs. This functional form has been used to measure scale and scope economies in the banking industry (see Pulley and Humphrey, 1993 and Pulley and Braunstein, 1992). The separable quadratic functional form is defined as:

\footnotetext{
${ }^{9}$ At least two other methods of measuring technological change exist. We could also include yearly dummy variables or event specific dummy variables (indicating the occurance of a specific event) (see Hancock, Humphrey, and Wilcox, 1999 and Bauer and Ferrier, 1996.) We prefer the smoothed time trends, since the changes to the Fed processing provision happen over an extended period of time.
} 


$$
\begin{aligned}
C & =\left[\alpha_{0}+\sum_{m} \alpha_{m} y_{m}+1 / 2 \sum \sum \alpha_{m l} y_{m} y_{l}\right. \\
& \left.+\quad \lambda_{1} t i m e+\lambda_{2} t i m e^{2}+\sum_{j=1}^{3} \phi_{j} Q T R_{j}+v_{i}+\mu_{i t}\right] \\
& \times \exp \left[\sum_{k} \beta_{k} \ln p_{k}+\sum \sum \beta_{k l} \ln p_{k} \ln p_{l}\right]+\mu_{i t}
\end{aligned}
$$

Lastly, besides these two functional forms, we also estimate a model with a structural shift in the cost function in 1997 - the year the transition to the new system was completed. We introduce a structural shift only through the outputs in the cost function. For the translog cost function, we get the following:

$$
\begin{aligned}
\ln C & =\sum_{k}^{K} \beta_{k} \ln p_{k}+\sum_{k}^{K} \sum_{l}^{K} \beta_{k l} \ln p_{k} \ln p_{l}+\left(\alpha_{10}+\sum_{m}^{M} \alpha_{1 m} \ln y_{m}\right. \\
& \left.+\sum_{m}^{M} \sum_{l}^{M} \alpha_{1 m l} \ln y_{m} \ln y_{l}+\lambda_{11} t i m e+\lambda_{21} t i m e^{2}+\sum_{j=1}^{3} \phi_{1 j} Q T R_{j}\right) \times d_{\text {pre } 97} \\
& +\left(\alpha_{20}+\sum_{m}^{M} \alpha_{2 m} \ln y_{m}+\sum_{m}^{M} \sum_{l}^{M} \alpha_{2 m l} \ln y_{m} \ln y_{l}+\lambda_{12} \text { time }+\lambda_{22} \text { time } e^{2}\right. \\
& \left.+\sum_{j=1}^{3} \phi_{2 j} Q T R_{j}\right) \times d_{\text {post } 97}+\mu_{i t} \\
& k=1, \cdots, 4 ; m=1, \cdots, 3
\end{aligned}
$$

The new separable quadratic functional form is: 


$$
\begin{aligned}
C & =\left(\left[\alpha_{10}+\sum_{m} \alpha_{1 m} y_{1 m}+1 / 2 \sum \sum \alpha_{1 m l} y_{1 m} y_{1 l}\right.\right. \\
& \left.+\quad \lambda_{11} \text { time }+\lambda_{21} t i m e^{2}+\sum_{j=1}^{3} \phi_{1 j} Q T R_{j}\right] \times d_{\text {pre } 97} \\
& +\quad\left[\alpha_{20}+\sum_{m} \alpha_{2 m} y_{2 m}+1 / 2 \sum \sum \alpha_{2 m l} y_{2 m} y_{2 l}\right. \\
& \left.\left.+\quad \lambda_{11} t i m e+\lambda_{21} t i m e^{2}+\sum_{j=1}^{3} \phi_{1 j} Q T R_{j}\right] \times d_{\text {post }}\right) \\
& \times \exp \left[\sum_{k} \beta_{k} \ln p_{k}+\sum \sum \beta_{k l} \ln p_{k} \ln p_{l}\right]+v_{i}+\mu_{i t}
\end{aligned}
$$

where $d_{p r e 97}$ is a dummy variable for all years prior to 1997 and $d_{p o s t 97}$ is a dummy variable for 1997 and all subsequent years.

\subsection{Economies of Scale and Scope:}

The traditional measures of scale and scope economies can be identified from properties of the cost function. Ray scale economies (RSCE) are measured as the elasticity of cost along a ray, $\theta \mathbf{y}$, emanating from the origin holding output bundles fixed.

$$
S C A L E=C(\underline{\mathrm{y}} ; \underline{\mathrm{p}}) /\left[\sum y_{i} \times\left(\partial C(\underline{\mathrm{y}} ; \underline{\mathrm{p}}) / \partial y_{i}\right)\right]
$$

Scale economies (diseconomies) exist when SCALE is greater (less) than one. Scope economies are measured as the percentage of cost savings from producing all outputs jointly relative to producing 
each output separately: ${ }^{10}$

$$
\begin{aligned}
S C O P E & =\left[C\left(y_{1}, 0, \cdots, 0 ; \underline{\mathrm{p}}\right)+C\left(0, y_{2}, 0, \cdots, 0 ; \underline{\mathrm{p}}\right)+\cdots+C\left(0, \cdots, 0, y_{m} ; \underline{\mathrm{p}}\right)\right. \\
& \left.-C\left(y_{1}, y_{2}, \cdots, y_{m} ; \underline{\mathrm{p}}\right)\right] / C\left(y_{1}, y_{2}, \cdots, y_{m} ; \underline{\mathrm{p}}\right)
\end{aligned}
$$

Scope economies (diseconomies) exist, when SCOPE is greater (less) than zero. Two concerns exist with these definitions. First, interpretation of RSCE measures is limited, when the product mix varies as output increases. Berger, Hanweck, and Humphrey (1986) developed a measure, expansion path scale economies (EPSCE), that allows for changing product mixes as output increases and hence gives a more general interpretation of scale economies. While this concern is warranted in the banking industry with a mixture of mega-banks and local community banks, it is not a major concern in our data. The product mix of the Reserve Banks is similar for all but one Reserve Bank.

Second, extrapolating results beyond the range of the data is problematic. Either the functional form is not well defined in specific ranges (e.g. the translog at zero) or the estimated function does not have any empirical support outside the observed range of the data. The "quasi" scope (QSCOPE) measure is designed to accommodate functional forms that are not well defined near zero. ${ }^{11}$ QSCOPE is based on the notion that, while firms produce a mixture of goods, they specialize in one and produce only an insignificant amount of all other outputs. Let $\epsilon$ be the proportion of nonspecialized outputs produced. QSCOPE is defined as:

\footnotetext{
${ }^{10}$ The notion of scope economies and cost subadditivity are interrelated notions of production. See Baumol, Panzar, and Willig (1988).

${ }^{11}$ See Berger, Hanweck, and Humphrey, 1987 and Pulley and Humphrey, 1993
} 


$$
\begin{aligned}
Q S C O P E & =\left[C\left(\{1-(m-1) \epsilon\} y_{1}, \epsilon y_{2}, \cdots, \epsilon y_{m} ; \underline{\mathrm{p}}\right)\right. \\
& +C\left(\epsilon y_{1},\{1-(m-1) \epsilon\} y_{2}, \epsilon y_{3}, \cdots, \epsilon y_{m} ; \underline{\mathrm{p}}\right) \\
& +C\left(\epsilon y_{1}, \epsilon y_{2}, \cdots,\{1-(m-1) \epsilon\} y_{m} ; \underline{\mathrm{p}}\right) \\
& \left.-C\left(y_{1}, y_{2}, \cdots, y_{m}, ; \underline{\mathrm{p}}\right)\right] / C\left(y_{1}, y_{2}, \cdots, y_{m}, ; \underline{\mathrm{p}}\right)
\end{aligned}
$$

where $\mathrm{m}$ is number number of outputs and $\mathrm{p}$ is a vector of input prices. When $\epsilon=0$, then QSCOPE is equivalent to the traditional measure of scope economies. It can be shown that $1 / \mathrm{m}$ is the maximum value for $\epsilon$, since no specialization occurs at this level.

\section{Data}

Data on total costs, output volumes, input prices, and environmental variables are collected for each of the 12 Federal Reserve district banks for the ACH, Book Entry, and Fedwire services for 44 quarterly observations over the years 1990 to 2000. Our primary data source was the annual functional cost accounting reports collected by the Federal Reserve's Planning and Control System (PACS). These data were supplemented with data from various Federal Reserve surveys, Bureau of Economic Analysis and Bureau of Labor Statistics price indexes, and pricing data from industry sources. 12

Table 1 reports the average values for the variables employed in this study. Total cost is the sum of the three services' activity production costs, which include direct and support costs, but exclude imputed costs and certain overhead expenses, such as special District projects. ${ }^{13}$ The processing

\footnotetext{
${ }^{12}$ Data construction parallels Bauer and Hancock (1992) and Bauer and Higgins (2002), who provide details.

${ }^{13}$ While overhead expenses represent a nontrivial proportion of total costs (approximately $30 \%$ ), the allocation of these costs can only be achieved using arbitrary accounting rules. For this reason, previous work on the Federal Reserve payment services concentrated on activity production costs and we want our results to be comparable.
} 
cost is composed of payments for four inputs-labor $(L)$, materials $(M)$, communications equipment and transit $(T)$, and buildings $(B)$.

The price of labor $\left(P_{L}\right)$ was constructed as the sum of expenditures on labor (including salaries, retirement, and other benefits) divided by the number of employee processing hours. Reflecting the high capital intensity of these services, labor's cost share is only $15 \%$.

Communications and transit expenditures consist of the costs associated with data and other communications, shipping, and travel. Communications costs form the bulk of these expenses. About $36 \%$ of Fedwire's costs are associated with this input category. The implicit price deflator for communications equipment purchases by nonresidential producers was used for data and other communications expenses. The aircraft price index for private purchases of producers' durable equipment was employed for shipping and travel expenditures. The price of transit is derived using a Tornquist approximation of a Divisia price. ${ }^{14}$

Similarly, the price of materials $\left(P_{M}\right), 40 \%$ of total cost, is also given by a Tornquist index. It was constructed from the service prices of supplies and machines. The service price of supplies (office equipment and supplies, and printing and duplicating) was represented by the implicit price deflator for gross domestic product (GDP). The service price of machines (computers and data processing) was constructed from cost-accounting expenditure data supplemented with the implicit price deflator for office, computing, and accounting machinery. To construct a price for data system support services (primarily used for in-house, product-specific software development), we utilized expenditures for labor and hours worked in that area of each Reserve Bank. For computer hardware, an estimate of the service value, or price, of machines was constructed using a perpetual inventory model derived by Hall and Jorgenson (1967).

Buildings have the smallest cost share among the four inputs, because the Federal Reserve

\footnotetext{
${ }^{14}$ The Tornquist index uses a weighted average of the growth rates for each input category. The weights are the shares of materials expenses attributable to each category averaged over adjoining periods.
} 
does not finance buildings; thus, interest expenses associated with the acquisition of fixed assets are not present in the PACS's cost-accounting framework. Instead, interest costs are included in the Private Sector Adjustment Factor (PSAF) used to set prices for Federal Reserve payments services. The cost share of buildings averages $2 \%$. The price of buildings $\left(P_{B}\right)$, measured as square-foot replacement costs adjusted by site-specific depreciation rates, was constructed using cost accounting information from the PACS data and annual replacement-cost indexes available from Means (2001).

Output variables are defined as follows. Our measure of output for the $\mathrm{ACH}$ service $\left(Y_{A C H}\right)$ is the same one employed by Bauer and Higgins (2002) and is the number of originations and receipts processed at a given site for observations after 1996 and an estimate of this number before. ${ }^{15}$ Book entry items $\left(Y_{B K}\right)$ is the total number of Book Entry transactions processed in each district. The measure of Fedwire output $\left(Y_{F W}\right)$ was measured as the total number of Fedwire funds transfers processed at each site.

\section{$5 \quad$ Results}

We estimate equations 2-5 (with respective share equations) using iterated 3SLS. We initially estimated a model with three outputs (ACH, Fedwire, and Book-Entry). However, the results for this specification were not particularly promising. Depending on the functional form and/or the treatment for structural change the three-output analyses gave conflicting temporal patterns and signs for the marginal costs of Book-Entry. We proceeded by estimating a new specification, where Fedwire and Book-Entry are aggregated together. This specification of the technology is sensible since a Book-Entry transaction is essentially a Fedwire transaction. We tested the hypothesis that the coefficients are the same for Fedwire and Book-Entry services using an F test and found it cannot

\footnotetext{
${ }^{15}$ See Bauer and Ferrier (1996) for details.
} 
be rejected at the 90 percent confidence level. Results for a two-output technology were much more reasonable and relatively robust across the different functional forms and treatments of structural change. The results we discuss below are based on disaggregating payment processing into two outputs: automated clearinghouse and fedwire services. ${ }^{16}$ Parameter estimates for equations 4 and 5 are provided in Tables 2 and 3.

First, we turn to our estimates of Qscope and scope economies. Tables 4 and 5 list average Qscope estimates for our four models. We use the following values of specialization, $\epsilon$ : $0.001,0.01$, 0.1 , and 0.3. Scope economies for translog models are measured at $\epsilon=0.000001$.

Our scope economy estimates are not robust and vary depending on the model. The standard translog model (equation 2) indicates scope economies that do not change with specialization. The translog with a shift model displays economies of scope until 1996 and diseconomies thereafter. As provision becomes less specialized (i.e., as $\epsilon$ gets larger), Qscope economies decrease. Qscope estimates also decrease over time and significant Qscope diseconomies are present in 2000.

The results from the separable quadratic models tell a mixed story as well. The standard separable quadratic model (equation 3) measures falling scope economies throughout the decade. Diseconomies result after 1996. These results do not change as the level of specialization, $\epsilon$, changes. The separable quadratic model with a shift (equation 5) also displays economies of scope for the first part of the decade. Scope economies fall until 1995, where diseconomies of scope are observed for two years. After 1997, the model displays economies of scope. However, Qscope estimates for this model are negative throughout the sample period for all levels of specialization.

Results for equation 5 scope estimates indicate that consolidation of Fed payments processing to three centers starting in 1993 did not have an immediate impact on scope economies, but lead to a decline in scope economies during the transition years. After completion in 1997, scope economies returned to a higher level than before the centralization policy was initiated.

\footnotetext{
${ }^{16}$ From this point on, Fedwire will include both Fedwire and Book-Entry payment services.
} 
Table 6 shows the average returns to scale. All models display an average economies of scale greater than 1. As others have found, our models reinforce the notion that scale economies exist in the provision of payment services. In a single product setting, Bauer and Ferrier (1996) find scale economies for $\mathrm{ACH}$, but not for Fedwire in their study. However, Hancock, Humphrey, and Wilcox (1999) recently measured scale economies for the provision of Fedwire.

We now turn to our estimates of technological change. Both translog specifications (equations 2 and 4) and the standard separable quadratic model (equation 3) show a somewhat similar rate of technical change. Equation 2 indicates that technical change started at around 1\% in 1990 and accelerated to around $3 \%$ in 2000 . In equation 4 , technical change starts at around $2 \%$, slows down during the next 4 years to less than $1 \%$ and then picks up again at $2 \%$ for the rest of the time period. In equation 3, we observe a similar trend in technical change as in equation 2. Technical change starts at $0.7 \%$ in 1990 and increases to $2 \%$ in 2000. Finally, technical change in equation 5 remains constant over the first half of the decade, remaining at $0.7 \%$ till 1996. In 1997, technical change jumps to $2 \%$ and then falls to $0.5 \%$ in 2000 .

Our results on technical change are comparable to results obtained in other studies. Hancock, Humphrey, and Wilcox (1999) report technical change of $0.8 \%$ to $1.4 \%$ for Fedwire. ${ }^{17}$ Bauer and Ferrier (1996) suggest that technical change averaged $6 \%$ annually. Our results are more consistent with those of Hancock, Humphrey, and Wilcox (1999).

Finally, we consider the marginal cost estimates. Tables 7 lists marginal costs for both translog and both separable quadratic functional forms. All models show a decrease in marginal costs for $\mathrm{ACH}$ and Fedwire. The translog model (equation 2) indicates a change in marginal costs of Fedwire transactions from 29 cents in 1990 to 13 cents in 2000 and a change in ACH from 3.6 cents to one cent. The results for the translog model with a shift (equation 4) indicate Fedwire marginal costs fell from 28 cents to five cents and $\mathrm{ACH}$ fell from 4.4 cents to 1.1 cents. Finally, the results for

\footnotetext{
${ }^{17}$ They also report that private-sector productivity growth over their sample period averaged $1.1 \%$.
} 
both the separable quadratic functional forms are similar. In equation 3, Fedwire costs fell from 28 cents to 20 cents and $\mathrm{ACH}$ costs fell from 2.7 cents to 1.4 cents. In equation 5, Fedwire costs fell from 40 cents to 22 cents and ACH costs fell from 2.7 cents to about one-half cent.

While the overall magnitude of changes in marginal costs vary significantly, our findings of falling marginal costs are robust across functional forms and treatment for structural change. We find Fedwire costs fell 29 percent to 82 percent from initial 1990 levels and ACH costs fell 48 percent to 85 percent from initial 1990 levels. These changes in marginal costs are fairly large, and indicate that changes in the Fed provision of payment services have led to an overall fall in per unit costs.

Although our results do not give definitive answers on the existence of scope economies, the current market structure tends to support the finding of little or no scope economies. This is consistent with institutional evidence that networks such as CHIPS, with significant market share in Fedwire, have not attempted to enter the ACH market. If scope economies existed, then CHIPS could enter the ACH market and reduce overall costs by providing both Fedwire and ACH products. Other anecdotes exist as well. For example, other networks such as Visa or MasterCard, which provide similar network services, also have not made significant entry into the ACH market. Presumably, the cost advantage in providing multiple services is not significant enough to overcome the advantages of scale economies. ${ }^{18}$ Our results also indicate that while entry has occurred on a small scale (EPN in $\mathrm{ACH}$ ), more significant entry may be difficult, because of the large scale necessary to obtain competitive marginal costs. The scope economies do not necessarily help with overcoming this cost disadvantage at the onset of entry. Hence, our results suggest that entry should occur on a large scale for a single product rather than across several products. Note that 80 percent of ACH originations comes from the 50 largest originators, so that only a relatively small number of banks would have to switch for a competitor to gain sizeable volume.

\footnotetext{
${ }^{18}$ There seems to be little financial incentive for entry as long as the Fed is marginal cost pricing. Also, entry by these networks in the near future would be evidence in favor of scope economies.
} 


\section{Conclusion}

In this paper, we investigate the existence of scale economies, scope economies and technical change in the provision of Federal Reserve payments services. To the extent that Federal Reserve payments processing is similar to services offered by other networks such as Visa, MasterCard, and CHIPS, this study will help gain insight into the productivity of networks that provide payments processing.

Using different functional forms and treatments for structural change due to new regulatory and administrative initiatives, we find significant and positive scale economies but little consistent evidence of significant and sizeable scope economies in the provision of payments processing. Our models indicate that technical change was relatively constant over the previous decade. We find that most of the marginal cost reduction can be attributed to scale economies, not to scope economies or technical change.

Our results indicate that the Federal Reserve was able to take advantage of scale economies in the provision of its payment services. Lower costs from scale economies appear to have deterred entry by other networks and decreased costs for the Federal Reserve. Also, because scope economies are not significant, the Federal Reserve's policy of managing each service as if it were a separate business that must recover costs appears to be reasonable.

\section{References}

[1] Bank for International Settlements (1995) "Payment Systems and the Group of Ten Countries," Basle, Switzerland, December.

[2] Bank for International Settlements (2000) "Payment Systems and the Group of Ten Countries," Basle, Switzerland, December. 
[3] Bauer, Paul W. and Ferrier, Gary D.(1996) "Scale Economies, Cost Efficiencies, and Technical Change in Federal Reserve Payments Processing," Journal of Money, Credit, and Banking 28(4) Pt. 2, 1004-39.

[4] Bauer, Paul W. and Ferrier, Gary D.(1997) "Evidence for Cost Complementarities in Federal Reserve Payments Processing," working paper.

[5] Bauer, Paul W. and Hancock, Diana (1995) "Scale Economies and Technological Change in the Federal Reserve ACH Payment Processing" Federal Reserve Bank of Cleveland Economic Review, 31(3), 14-29.

[6] Baumol, William J., Panzar, John C., Willig, Robert D. (1988) Contestable Markets and the Theory of Industrial Structure

[7] Berger, Allen N., Hanweck, Gerald A., and Humphrey, David B. (1987) "Competitive Viability in Banking: Scale, Scope, and Product Mix Economies," Journal of Monetary Economics 20, $501-20$.

[8] Berger, Allen N., Hancock, Diana, Marquardt, Jeffrey C. (1996) “A Framework for Analyzing Efficiency, Risk, Costs, and Innovations in the Payments System," Journal of Money, Credit, and Banking Vol. 28, No. 4, 696-732.

[9] Berger, Allen N. and Mester, Loretta J. (1997) "Inside the Black Box: What Explains The Differences in Efficiencies of Financial Insituttions," Journal of Banking and Finance v. 21, Iss. $7,895-947$.

[10] Hancock, Diana and Humphrey, David-B. (1997) "Payment Transactions, Instruments, and Systems: A Survey," Journal of Banking and Finance, vol. 21, iss. 11-12, 1573-1624. 
[11] Hancock, Diana, Humphrey, David-B., Wilcox,-James. (1999) "Cost Reductions in Electronic Payments: The Roles of Consolidation, Economies of Scale, and Technical Change," Journal of Banking and Finance, Vol. 23, No. 2-4, February 1999, pages 391-421.

[12] Humphrey, David B. (1980) "Are There Economies of Scale in Check Processing at the Federal Reserve?," Journal of Bank Research 11, 8-19.

[13] Humphrey, David B. (1981) " Scale Economies at Automated Clearinghouses," Journal of Bank Research 12, 71-81.

[14] Humphrey, David B. (1984) "The U.S. Payments System: Costs, pricing, Competition and Risk," Monograph Series in Finance and Economics, Monograph 1984-1/2.

[15] Humphrey, David B. and Berger, Allen N. (1990) "Market Failure and Resource Use: Economic Incentives to Use Different Payment Instruments," in The U.S. Payment System: Efficiency, Risk and the Role of the Federal Reserve, Kluwer Academic Publishers, 45-86.

[16] Knudson, Scott E., Walton, Jack K., and Young, Florence M. (1994) "Business-to-business payments and the role of financial electronic data interchange." Federal Reserve Bulletin, Board Of Governors Of The Federal Reserve System. April, 269-278.

[17] Lovell, C. A. Knox, and Sickles, Robin C. (1999) "Causes and Consequences of Expert Disagreement: Methodological Lessons From the U.S. V. AT\&T Debate," in The Role of the Academic Economist in Litigation Support, edited by Daniel Slotjje, Amsterdam: North-Holland, 189-206.

[18] McAllister, Patrick H. and McManus, Douglas (1993) "Resolving the Scale Efficiency Puzzle in Banking," Journal of Banking and Finance 17, 389-406. 
[19] Means, R.S. Means Construction Cost indexes, Vol. 27, No. 1, Jan. 2001, R.S. Means Co., Kingston, MA.

[20] Röller, Lars-Hendrik (1990) "Proper Quadratic Cost Functions with an Application to AT\&T. Review of Economic Statistics, 72(No. 2/May), pp. 22-210.

[21] Wells, Kirstin E. (1996) "Are checks overused?," Quarterly Review, Federal Reserve Bank Of Minneapolis, Fall, p. 2-12. 
Table 1: Means of Raw Variables

\begin{tabular}{ccccc} 
Variable & Mean & Std Dev & Minimum & Maximum \\
\hline YACH & $59,215,437$ & $35,267,901$ & $11,787,570$ & $187,783,000$ \\
YBE & 567,817 & $1,346,297$ & 8398 & $5,967,891$ \\
YFW & $3,088,869$ & $3,210,303$ & 624,968 & $20,405,712$ \\
PL & 25.86 & 6.74 & 15.03 & 57.87 \\
PM & 1.07 & 0.033 & 1.00 & 1.12 \\
PB & 3.48 & 0.58 & 2.43 & 4.98 \\
PT & 0.95 & 0.051 & 0.86 & 1.02 \\
C & $2,584,459$ & $1,558,025$ & $1,114,573$ & $8,510,849$ \\
LSHARE & 0.15 & 0.04 & 0.06 & 0.28 \\
MSHARE & 0.47 & 0.07 & 0.28 & 0.64 \\
BSHARE & 0.02 & 0.007 & 0.009 & 0.06 \\
TSHARE & 0.36 & 0.06 & 0.22 & 0.54
\end{tabular}


Table 2: Cost Function Parameter Estimates - Equation 5

\begin{tabular}{|c|c|c|c|}
\hline Parameter & Estimate & StdErr & t-statistic \\
\hline$Y A_{\text {pre } 97}$ & 0.0163 & 0.00174 & 9.36 \\
\hline$Y F_{\text {pre } 97}$ & 0.189 & 0.0174 & 10.89 \\
\hline$Y A_{p r e 97}^{2}$ & $-152 \mathrm{E}-12$ & $2.63 \mathrm{E}-11$ & -5.76 \\
\hline$Y A F_{\text {pre } 97}$ & $-637 \mathrm{E}-13$ & $2.32 \mathrm{E}-10$ & -0.27 \\
\hline$Y F_{p r e 97}^{2}$ & $-4.19 \mathrm{E}-9$ & $2.849 \mathrm{E}-9$ & -1.47 \\
\hline$Y A_{\text {post } 97}$ & 0.00334 & 0.00193 & 1.73 \\
\hline$Y F_{\text {post } 97}$ & 0.221 & 0.0150 & 14.68 \\
\hline$Y A_{\text {post } 97}^{2}$ & $4.8 \mathrm{E}-11$ & $1.89 \mathrm{E}-11$ & 2.54 \\
\hline$Y A F_{\text {post } 97}$ & $-1.12 \mathrm{E}-9$ & $1.7 \mathrm{E}-10$ & -6.59 \\
\hline$Y F_{\text {post } 97}^{2}$ & $-2.37 \mathrm{E}-9$ & $1.167 \mathrm{E}-9$ & -2.03 \\
\hline time & -14739.2 & 4658.0 & -3.16 \\
\hline time $e_{p r e 97}^{2}$ & -34.520 & 153.0 & -0.23 \\
\hline time $e_{\text {post }} 97$ & -127698 & 44398.2 & -2.88 \\
\hline time $e_{\text {post } 97}^{2}$ & 1388.522 & 606.0 & 2.29 \\
\hline$P_{l}$ & 0.366 & 0.0194 & 18.88 \\
\hline$P_{m}$ & 0.515 & 0.0412 & 12.48 \\
\hline$P_{b}$ & 0.00655 & 0.00428 & 1.53 \\
\hline$P_{l} P_{m}$ & -0.0110 & 0.0138 & -0.80 \\
\hline$P_{l} P_{b}$ & 0.00293 & 0.00184 & 1.60 \\
\hline$P_{l} P_{t}$ & 0.0752 & 0.0114 & 6.62 \\
\hline$P_{b} P_{m}$ & -0.0489 & 0.00460 & -10.63 \\
\hline$P_{m} P_{t}$ & -0.368 & 0.0404 & -9.12 \\
\hline$P_{b} P_{t}$ & 0.0378 & 0.00372 & 10.15 \\
\hline
\end{tabular}

Notes: The above regression includes a constant term and quarterly dummy variables, which are not shown in this table. 
Table 3: Translog Cost Function Parameter Estimates

\begin{tabular}{cccc} 
Parameter & Estimate & StdErr & t-statistic \\
\hline$Y A_{\text {pre } 97}$ & 1.988 & 1.0298 & 1.93 \\
$Y F_{\text {pre } 97}$ & -2.976 & 0.6440 & -4.62 \\
$Y A_{\text {pre } 97}^{2}$ & -0.0406 & 0.0766 & -0.53 \\
$Y F_{\text {pre } 97}^{2}$ & 0.293 & 0.0334 & 8.78 \\
$Y A F_{\text {pre } 97}$ & -0.0577 & 0.0404 & -1.43 \\
$Y F_{\text {post } 97}$ & 1.625 & 1.0462 & 1.55 \\
$Y A_{\text {post } 97}$ & -5.904 & 1.8358 & -3.22 \\
$Y A_{\text {post } 97}^{2}$ & 0.711 & 0.1486 & 4.79 \\
$Y F_{\text {post } 97}^{2}$ & 0.436 & 0.0411 & 10.62 \\
$Y A F_{\text {post }} 97$ & -0.438 & 0.0786 & -5.57 \\
time & -0.0214 & 0.00512 & -4.19 \\
time $e_{\text {pre } 97}^{2}$ & 0.00032 & 0.000194 & 1.65 \\
time $e_{\text {post } 97}$ & -0.0223 & 0.0212 & -1.05 \\
time $e_{\text {post }}^{2} 97$ & -0.00002 & 0.000305 & -0.07 \\
$P_{l}$ & 0.369 & 0.0195 & 18.87 \\
$P_{m}$ & 0.508 & 0.0415 & 12.23 \\
$P_{b}$ & 0.00879 & 0.00432 & 2.03 \\
$P_{l} P_{m}$ & -0.00921 & 0.0139 & -0.66 \\
$P_{l} P_{b}$ & 0.00151 & 0.00187 & 0.81 \\
$P_{l} P_{t}$ & 0.0750 & 0.0114 & 6.57 \\
$P_{m} P_{b}$ & -0.0477 & 0.00462 & -10.32 \\
$P_{m} P_{t}$ & -0.366 & 0.0405 & -9.05 \\
$P_{b} P_{t}$ & 0.0363 & 0.00375 & 9.68
\end{tabular}

Notes: The above regression includes a constant term and quarterly dummy variables, which are not shown in this table. 
Table 4: Scope and QSCOPE Estimates - Translog

\begin{tabular}{|c|c|c|c|c|c|c|c|c|c|c|c|}
\hline & 1990 & 1991 & 1992 & 1993 & 1994 & 1995 & 1996 & 1997 & 1998 & 1999 & 20000 \\
\hline & \multicolumn{11}{|c|}{ Translog - Eq2 } \\
\hline Scope & 0.51 & 0.52 & 0.54 & 0.55 & 0.56 & 0.57 & 0.56 & 0.56 & 0.53 & 0.54 & 0.55 \\
\hline QScope & & & & & & & & & & & \\
\hline$\epsilon=0.001$ & 0.49 & 0.51 & 0.53 & 0.54 & 0.55 & 0.55 & 0.55 & 0.55 & 0.52 & 0.53 & 0.54 \\
\hline$\epsilon=0.01$ & 0.49 & 0.50 & 0.52 & 0.53 & 0.54 & 0.55 & 0.55 & 0.55 & 0.52 & 0.53 & 0.53 \\
\hline$\epsilon=0.1$ & 0.48 & 0.49 & 0.51 & 0.52 & 0.53 & 0.54 & 0.54 & 0.54 & 0.51 & 0.52 & 0.52 \\
\hline \multirow[t]{2}{*}{$\epsilon=0.3$} & 0.48 & 0.49 & 0.51 & 0.52 & 0.53 & 0.54 & 0.54 & 0.53 & 0.50 & 0.51 & 0.52 \\
\hline & \multicolumn{11}{|c|}{ Translog - Eq4 } \\
\hline Scope & 0.55 & 0.57 & 0.58 & 0.59 & 0.61 & 0.61 & -0.58 & -0.67 & -0.74 & -0.85 & -0.95 \\
\hline QScope & & & & & & & & & & & \\
\hline$\epsilon=0.001$ & 0.11 & 0.13 & 0.15 & 0.16 & 0.17 & 0.18 & -2.64 & -2.74 & -2.82 & -2.93 & -3.05 \\
\hline$\epsilon=0.01$ & -0.033 & -0.017 & 0.0018 & 0.013 & 0.027 & 0.034 & -3.32 & -3.43 & -3.51 & -3.63 & -3.74 \\
\hline$\epsilon=0.1$ & -0.17 & -0.16 & -0.14 & -0.13 & -0.11 & -0.10 & -3.98 & -4.09 & -4.17 & -4.29 & -4.41 \\
\hline$\epsilon=0.3$ & -0.23 & -0.21 & -0.19 & -0.18 & -0.17 & -0.16 & -4.24 & -4.35 & -4.42 & -4.55 & -4.67 \\
\hline
\end{tabular}

Notes: Scope for translog functional forms is calculated at $\epsilon=0.000001$. 
Table 5: Scope and QSCOPE Estimates - Separable Quadratic

\begin{tabular}{|c|c|c|c|c|c|c|c|c|c|c|c|}
\hline & 1990 & 1991 & 1992 & 1993 & 1994 & 1995 & 1996 & 1997 & 1998 & 1999 & 20000 \\
\hline & \multicolumn{11}{|c|}{ Separable Quadratic - Eq3 } \\
\hline Scope & 0.38 & 0.35 & 0.30 & 0.25 & 0.19 & 0.13 & 0.07 & -0.006 & -0.043 & -0.13 & -0.22 \\
\hline QScope & & & & & & & & & & & \\
\hline$\epsilon=0.001$ & 0.38 & 0.35 & 0.30 & 0.25 & 0.19 & 0.13 & 0.068 & -0.006 & -0.044 & -0.13 & -0.22 \\
\hline$\epsilon=0.01$ & 0.38 & 0.35 & 0.30 & 0.25 & 0.19 & 0.13 & 0.068 & -0.006 & -0.044 & -0.13 & -0.22 \\
\hline$\epsilon=0.1$ & 0.38 & 0.35 & 0.30 & 0.25 & 0.19 & 0.13 & 0.069 & -0.005 & -0.04 & -0.13 & -0.22 \\
\hline \multirow[t]{2}{*}{$\epsilon=0.3$} & 0.39 & 0.35 & 0.31 & 0.26 & 0.20 & 0.14 & 0.088 & 0.019 & -0.014 & -0.089 & -0.16 \\
\hline & \multicolumn{11}{|c|}{ Separable Quadratic - Eq5 } \\
\hline Scope & 0.27 & 0.21 & 0.15 & 0.079 & 0.011 & -0.058 & -0.13 & 0.51 & 0.47 & 0.43 & 0.43 \\
\hline QScope & & & & & & & & & & & \\
\hline$\epsilon=0.001$ & -0.09 & -0.20 & -0.32 & -0.44 & -0.56 & -0.69 & -0.79 & -0.17 & -0.12 & -0.18 & -0.28 \\
\hline$\epsilon=0.01$ & -0.09 & -0.19 & -0.31 & -0.43 & -0.55 & -0.67 & -0.78 & -0.17 & -0.11 & -0.16 & -0.26 \\
\hline$\epsilon=0.1$ & -0.04 & -0.14 & -0.25 & -0.35 & -0.46 & -0.56 & -0.65 & -0.10 & -0.25 & -0.45 & -0.11 \\
\hline$\epsilon=0.3$ & -0.04 & -0.034 & -0.11 & -0.19 & -0.27 & -0.34 & -0.40 & -0.0017 & 0.11 & 0.13 & 0.10 \\
\hline
\end{tabular}

Table 6: Average Returns to Scale

\begin{tabular}{ll} 
Model & RTS \\
\hline Translog Eq. 2 & 1.42 \\
Translog Eq. 4 & 1.49
\end{tabular}

Separable Quadratic Eq. $3 \quad 1.45$

Separable Quadratic Eq. $5 \quad 1.26$ 
Table 7: Marginal Costs

Translog-Eq 2 Translog-Eq 4 Quadratic-Eq 3 Quadratic-Eq 5

\begin{tabular}{c|cc||cc||cc||cc}
\hline Year & Fedwire & ACH & Fedwire & ACH & Fedwire & ACH & Fedwire & ACH \\
\hline 1990 & 0.29 & 0.036 & 0.28 & 0.044 & 0.28 & 0.027 & 0.40 & 0.027 \\
1991 & 0.28 & 0.034 & 0.29 & 0.040 & 0.28 & 0.027 & 0.41 & 0.026 \\
1992 & 0.25 & 0.030 & 0.28 & 0.032 & 0.28 & 0.026 & 0.41 & 0.024 \\
1993 & 0.23 & 0.027 & 0.28 & 0.028 & 0.28 & 0.026 & 0.42 & 0.023 \\
1994 & 0.21 & 0.024 & 0.27 & 0.024 & 0.27 & 0.025 & 0.41 & 0.021 \\
1995 & 0.21 & 0.023 & 0.29 & 0.022 & 0.26 & 0.023 & 0.41 & 0.018 \\
1996 & 0.18 & 0.018 & 0.17 & 0.008 & 0.24 & 0.021 & 0.40 & 0.015 \\
1997 & 0.17 & 0.016 & 0.13 & 0.010 & 0.24 & 0.020 & 0.31 & 0.005 \\
1998 & 0.16 & 0.012 & 0.12 & 0.008 & 0.22 & 0.018 & 0.29 & 0.004 \\
1999 & 0.14 & 0.011 & 0.09 & 0.010 & 0.21 & 0.016 & 0.25 & 0.004 \\
2000 & 0.13 & 0.010 & 0.05 & 0.011 & 0.20 & 0.014 & 0.22 & 0.005
\end{tabular}

